\title{
IN MEMORIAM PROFESSOR TOIVO JÜRIMÄE 9 May 1949 - 5 October 2015
}

In autumn 2015, Professor Emeritus Toivo Jürimäe, an eminent sport scientist from the University of Tartu, passed away. His research work was mainly related to sport pedagogy, sport physiology and kinanthropometry.

He studied at the University of Tartu and graduated in 1973 with the diploma of a physical education teacher. For short time, he worked as a schoolteacher. In 1977, he returned to the University as Lecturer and earned the degree of Candidate of Biology (equal to $\mathrm{PhD}$ ) by defending his thesis in the field of physical abilities in young endurance athletes. Toivo Jürimäe became Professor of Sport Pedagogy in 1992, and worked at this position until becoming Professor Emeritus in 2012.

His main research topics in the University were focused on different relationships between anthropometrical parameters, health and physical performance in children, young athletes and elderly people. Being hard-working and consistent, he was able to do a lot. Under his supervision, eleven doctoral theses were defended in the period from 1996 to 2014. In addition, he supervised more than 20 master's theses. He has also supervised international students from Latvia, Lithuania and Italy on their way to reach a $\mathrm{PhD}$ in Exercise and Sport Science. More than 200 scientific publications in international journals and numerous monographs characterise his contribution to sport science.

Cooperation with different scientists and institutions was one of the aspects to which Toivo Jürimäe greatly contributed. He established numerous contacts and developed research cooperation between the Faculty of Exercise and Sport Science and different universities (for example, Tel Aviv University, Graz University, Liverpool John Moores University, Kazan University, University of North Texas, Catholic University of Leuven), which resulted in numerous scientific publications and student exchange. One of the aspects that Toivo considered important was cooperation between the Baltic countries in sport science. Being the leader, he organised the first congress of Baltic sport scientists in Tartu in 2008. Consequently, the Baltic Sport Science Society was established 
in 2009 and Toivo Jürimäe was elected its first President. Since then the Society has been very active with annual conferences held each year, and one part of the conference is always dedicated to $\mathrm{PhD}$ students to give them an opportunity to present their research in an international context - that idea came from Toivo Jürimäe. Toivo also managed to organise three congresses of international scientific organisations in Estonia: in 2001 - the $7^{\text {th }}$ International Conference of Sport Kinetics (Tartu); in 2003 - the $23^{\text {rd }}$ ICPAFR International Sport Science Symposium (Tartu), and in 2007 - the $24^{\text {th }}$ Pediatric Work Physiology Meeting (Tallinn, Laulasmaa). We may say that one of the reasons why the Faculty of Exercise and Sport Science succeeded in organising those events was Toivo's reputation among scientists.

In the Faculty of Exercise and Sport Sciences, Toivo Jürimäe was Head of the Institute of Sport Pedagogy and also Vice Dean for Research. In 1990, he established our scientific journal and was its editor-in-chief until 2012. Since 1996, the title of the journal has been Acta Kinesiologiae Universitatis Tartuensis, and currently it has an international editorial board and is indexed in several databases.

Toivo Jürimäe has made a lasting contribution to sport science is ongoing his published manuscripts are continuously referred to and many of his students are active in research.

Colleagues from the Institute of Sport Sciences and Physiotherapy, University of Tartu 